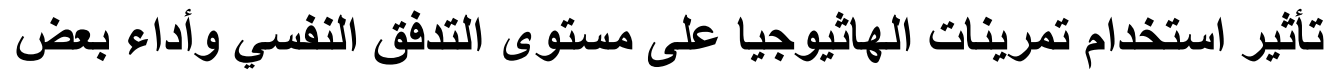

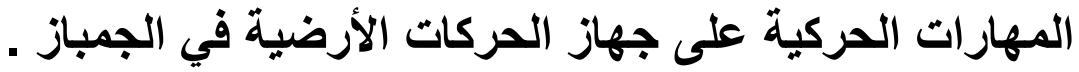

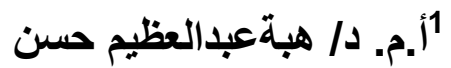

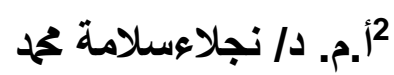

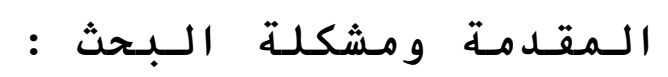

يشهح العالم الآن تطوراً هائلاً في المجال الرئل الرياضي، وطفرة كبيرة في الاهتمام بالعلوم

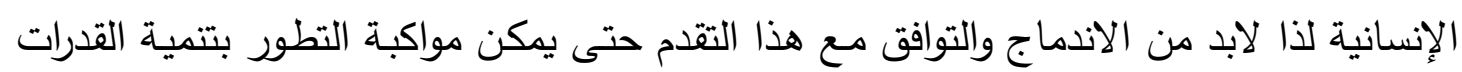

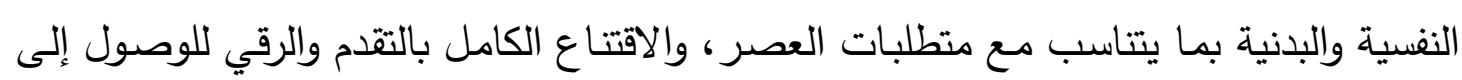
أعلى المستويات. ويــتقفكلمن " هويدالالعصـــــرة " ( 2008 م ) ، "رافــــــع الزغلــــــول " (2007م)

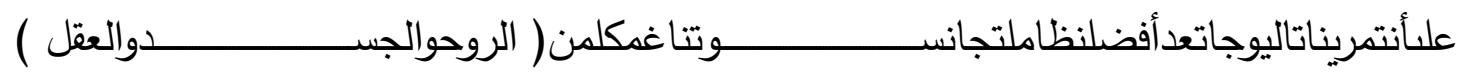

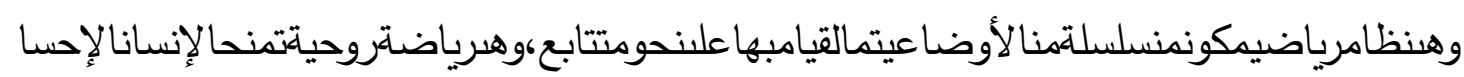

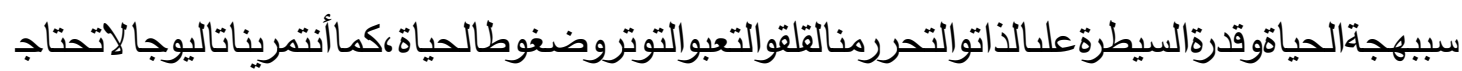

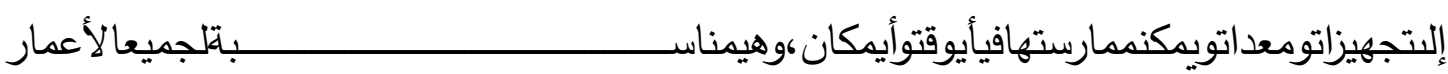

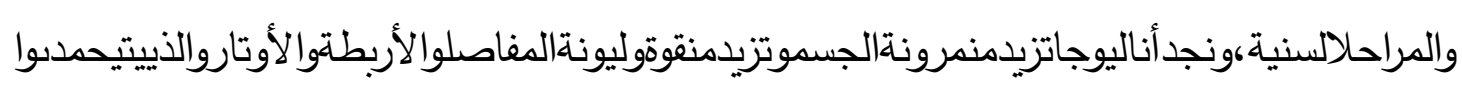

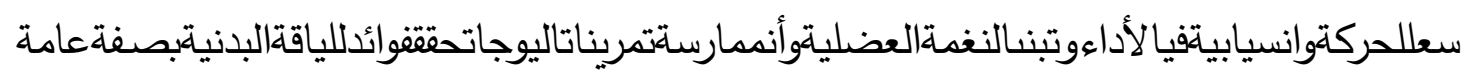

ويرى "ميلادكريجسىMiladaKrajci" ( 2003 م ) أن تمرينات اليوجا تسـاعد في ولي

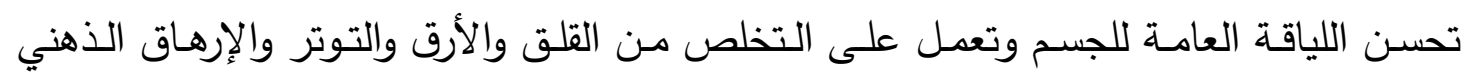
وتحسن من صفاء الذهن وتساعد على التفكير السليم • (14: 25 ) هناكالعديد من الدراساتالعلميةالتيتناولت تمرينات اليوجا مثل دراسة قامت بها "إلهام فرج

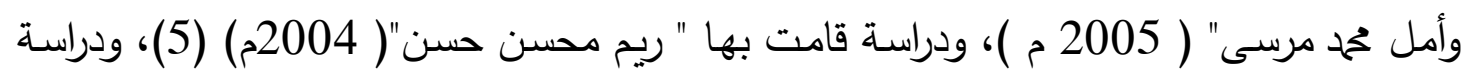

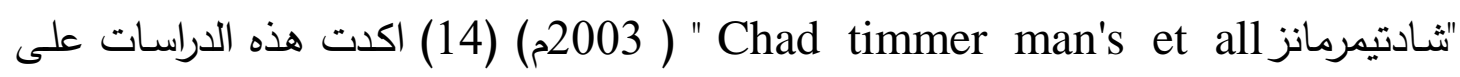
الفوائد العميقة التي تعود على الفرد بكل جوانبهمن ممارسـة تمرينات اليوجـا وقدتتاولت كافة

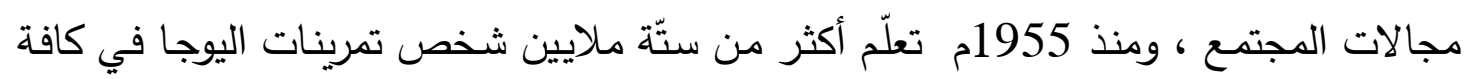
أنحاء العالم.(52:1)(89:16)(84:14)(41:)

1أستاذمساعدبقسمالتندريبالرياضيو علومالحركة- كلية/لتربية|الرياضية - جامعةأسيوط. 2أستاذمساعدبقسمتدريبالجمباز - كليةالتربيةالرياضيةلللبنات - جامعةطلوان. 
ولمزيد منالنجاح المحكم المحققأيضا يمكن أخذ خطوات أبعد في اتجاهالإيجابيتلوصول

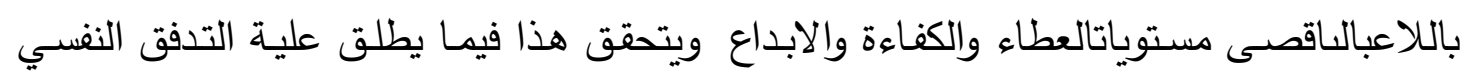

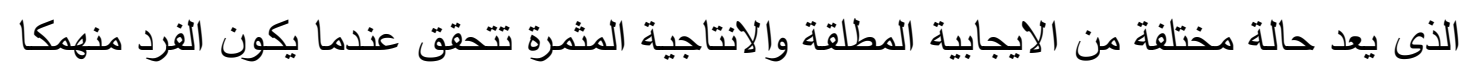
بكل كيانه في مهمة تثير دوافعه الذاتية الداخلية.(62:11) وتظهر هذ الحالة مع الاداءالامثل فيما يطلق علية في علم النفس الإيجابي(حالة|التدفق النفسي ) State Flow Psychlogical الثخصيةتدون افتقاد للوجهة والمسـارمع اسقاط للوقت من الحسـابات بمعنى تظل فاعليـة من

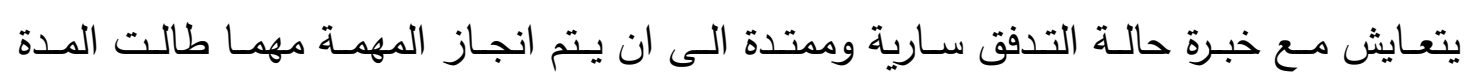
الزمنية.(62:8)

وتعتبر رياضـة الجمباز من أنواع الأنشطة الرياضية التي تمتاز بصفة الشمولية في

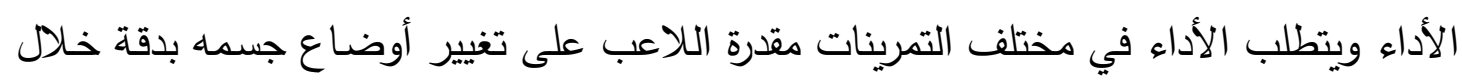
حركاته في الهواء وتزداد درجة تحمل الأجهزة الوظيفية لاستقبال التمرينات المختلفة.(102:18)

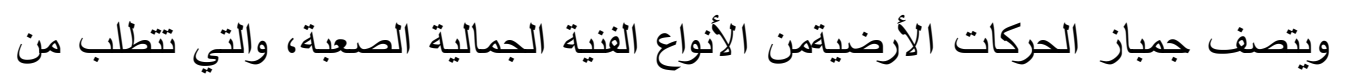

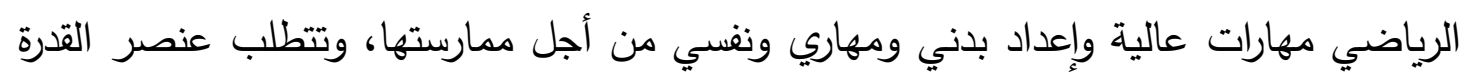

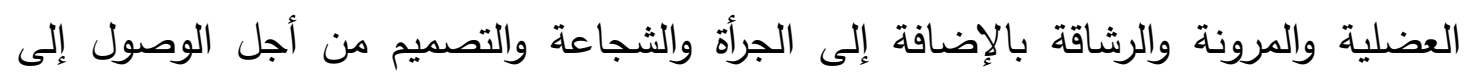
مستويات متقدمة. (85:23)

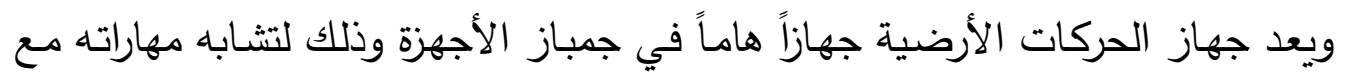

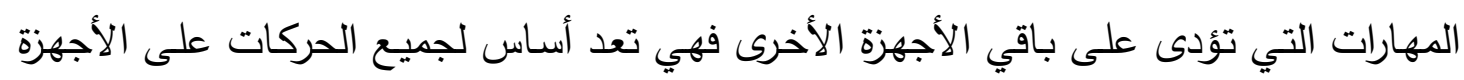

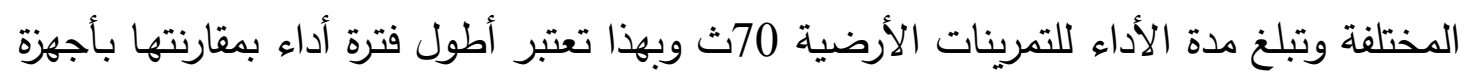

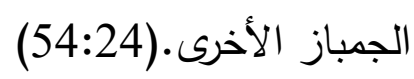

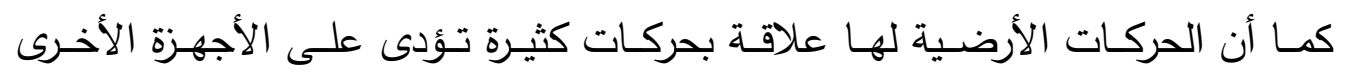

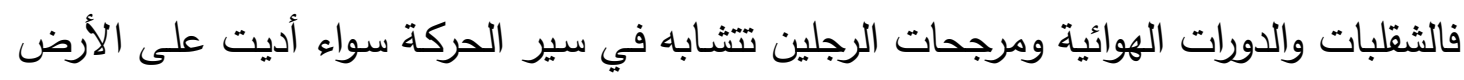

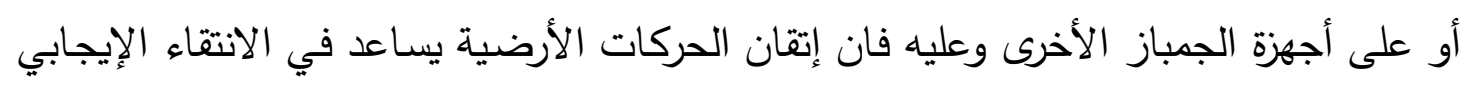

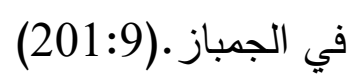

وقد لاحظت الباحثة من خلال تدريسها لمادة الجمباز لطالبات الفرقة الثالثة بكلية التربية

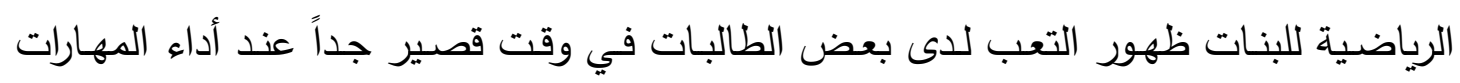
المقررة للجمباز على جهاز الحركات الارضية وذلك لفقد جهد كبير غير موجهة في الاداء 
المهارى نتيجة عدم التركيز، ويعتمد مستوى الأداء في الجمباز على مستوى الانسيابية في

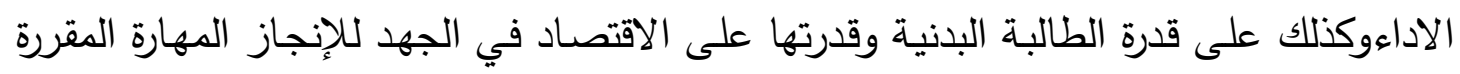

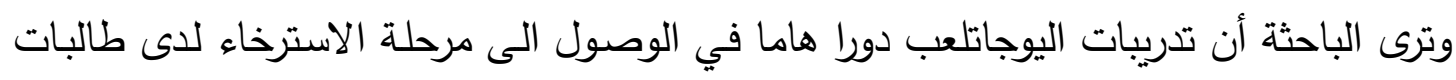

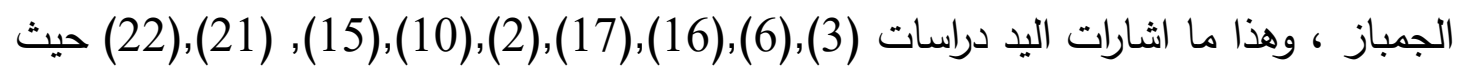

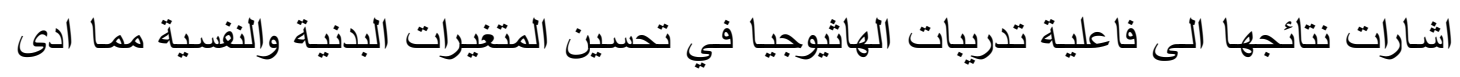

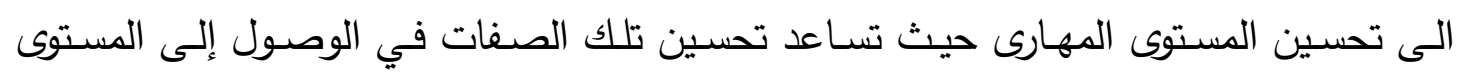

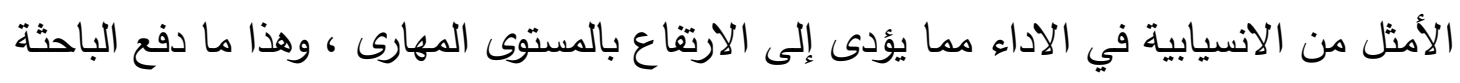

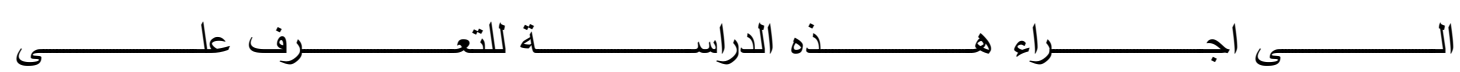
تأثيراستخد امتمريناتالهاثيوجيا علمستوبالتدفقالنفسيوأداءبعضالمهاراتالحركية علجهازالحركاتالأرضيةفي.

$$
\begin{aligned}
& \text { الجمباز . }
\end{aligned}
$$

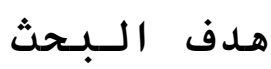

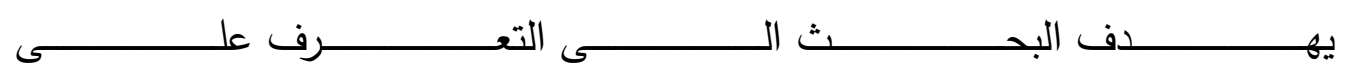

تأثيراستخدامتمريناتالهاثيوجياعلمستوبالتدفقالنفسيوأداءبعضالمهاراتالحركية علنجازالحركاتالأرضيةفيا

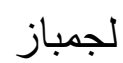

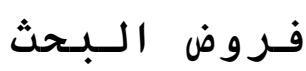

- توجد فروق ذات دلالة احصائية بين متوسطات القياسات القبلية والبعدية في مستوى

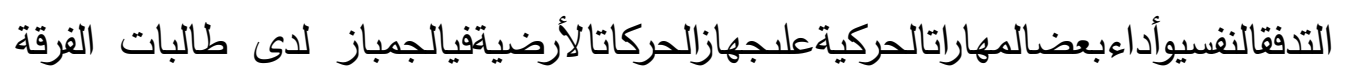
الثالثة مجموعة البحث التجريبية. - توجد فروق ذات دلالة احصائية بين متوسطات القياسات القبلية والبعدية في مستوى

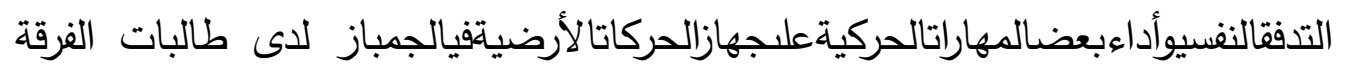
الثالثة مجموعة البحث الضابطة. - توجد فروق ذات دلالة احصائية بين متوسطي القياسين البعديين لاى مجموعتي البحث التجريبية

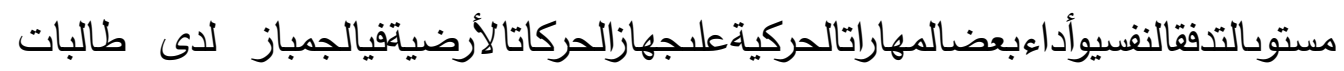
الفرقة الثالثة مجموعة البحث التجريبية. 
إحدى أنواع تدريبات اليوجا وهى عبارة عن مجموعة من التمرينات العقلية والأوضاع

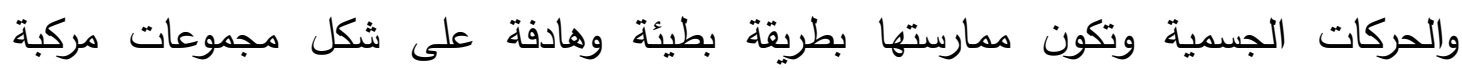
(78:19). (19) (19تابعة

State Flow Psychlogical التدفق النفسي استغراق الإنسانبكامل منظومات الشخصيةدون افتقاد للوجهة والمسارمع اسقاط للوقت

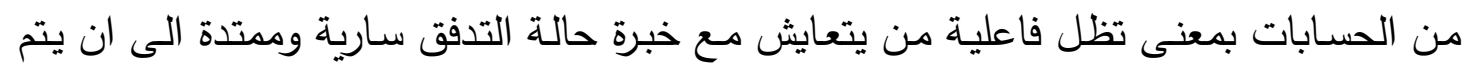

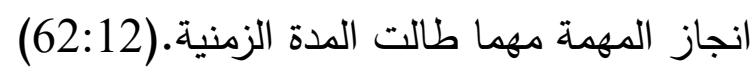
خطة وإجراء ات البحث

استخدمتالباحثةالمنهجالتجريبياسـتخداممجموعتين احـدهما تجريبـــة والاخـرى ضـابطة بأسلوبالقياسالبعديلملائمتهلطبيعةالبحث.

\section{مجتمع وعينة|لبحث}

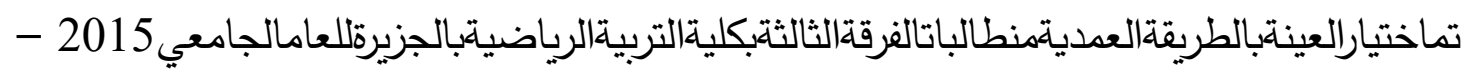
2016واللاتييتراوحأعمارهنبين (19-20)عاموبلغعددهن(38) طالبـة تم استخدام عينـة اساسية

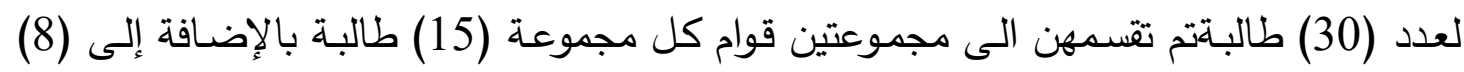
لإجراءالدراساتالاستطلاعية للبحث ومن خارج العينة الأساسية. أسباباختيارالعينة اختارت الباحثة العينة من طالبات الفرقة الثالثة للأسباب الآتية :

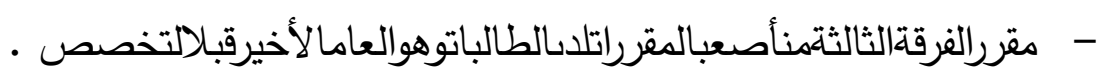
-

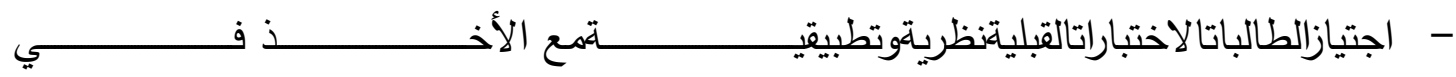

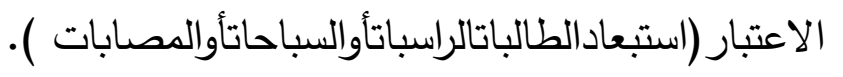

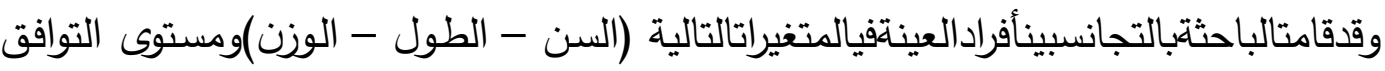
النفسي والاداء المهارى على جهاز الحركات الارضية لجميع أفراد العينة. 


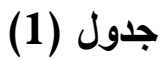

تجانس عينة البحث

$38=\dot{0}$

\begin{tabular}{|c|c|c|c|c|c|c|}
\hline الالتواء & الانحراف & الوسيط & المتوسط & ولقياس & المتغيرات & \\
\hline 0.28 & $\overline{028}$ & $\overline{19.00}$ & $\overline{19.20}$ & سنة & السن & \multirow{3}{*}{ 青宣 } \\
\hline 0.62 & 0.63 & 167.90 & 167.98 & سم & الطول & \\
\hline 0.14 & 0.21 & 65.90 & 65.98 & كجم & الـوزن & \\
\hline$\overline{0.25}$ & $\overline{0.41}$ & 2.10 & 2.11 & درجة & لدحرجة خلفية وقوف على اليدين & \multirow{5}{*}{ 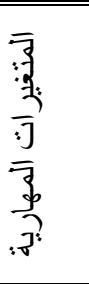 } \\
\hline 0.63 & 0.22 & 2.35 & 2.36 & ل درجة & عجلة فتحا من الجري & \\
\hline 0.55 & 0.16 & 2.10 & 2.14 & درجة & العجلة ضم مع ربع لفة & \\
\hline 0.18 & $\mathbf{0 . 5 8}$ & 2.60 & 2.62 & درجة & وقوف على اليدين دحرجة امامية & \\
\hline 0.27 & 0.11 & 2.15 & 2.16 & 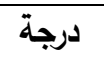 & وقوف على اليدين نزول على الصدر & \\
\hline 0.69 & 3.97 & 53.00 & 53.69 & درجة & \multicolumn{2}{|l|}{ التدفق النفسي } \\
\hline 0.21 & 29.30 & 29.00 & 29.15 & 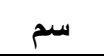 & الوثب العمودي من الثبات & \multirow{4}{*}{ 事承 } \\
\hline 0.17 & 14.80 & 14.10 & 14.60 & زمن & الجري المكوكي & \\
\hline 0.32 & 1.50 & 5.60 & 5.62 & سم & ثنى الجزع اسفل & \\
\hline 0.22 & 4.40 & 3.95 & 3.98 & 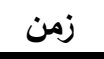 & الوقوف على عارضة التوازن & \\
\hline
\end{tabular}

يتضـح مـن الجدول رقم (1) أن معاملات الالتواء لعينة البحث الكليـة في متغيرات النمو

ومستوى التدفق النفسي والمتغيرات البدنية والاداء المهارى على جهاز الحركات الارضية قد تراوحت بين(0.14، 0.69)أي انحصرت بين(年) مما يدل على أن عينة البحث الكلية تمثل مجتمعاً اعتدالياً طبيعياً .

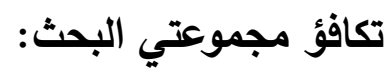

قامت الباحثة بإيجاد التكافؤ بين المجموعتين التجريبية والضـابطة في ضوء المتغيرات

التالية: معدلات النمو " السن، الطول، الوزن "، مستوى التدفق النفسي, مستوى المتغيرات البدنية

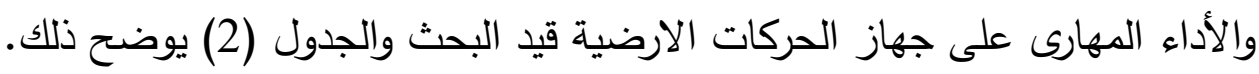




\section{جدول (2)}

التكافؤ بين المجموعتين الضابطة والتجريبية في كل من معدلات النمو والقدرات البلنية، والمهارات النفسيةومستوى الأداء المهارى للمهارات قيد البحث

$(\mathbf{3 0}=\mathbf{i})$

\begin{tabular}{|c|c|c|c|c|c|c|c|c|}
\hline \multirow{2}{*}{ مسلالة } & \multirow{2}{*}{ قيمة (ت) } & \multicolumn{2}{|c|}{ المجموعة الضابطة } & \multicolumn{2}{|c|}{ المجموعة التجريبية } & \multirow{2}{*}{ والقياس } & & \multirow[b]{2}{*}{ 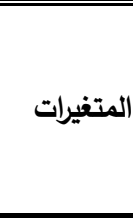 } \\
\hline & & $\underline{\underline{E}}$ & $\underline{E}$ & E. & $\underline{E}$ & & & \\
\hline غير دال & $\overline{0.62}$ & 0.32 & 19.21 & $\overline{\mathbf{0 . 2 8}}$ & 19.10 & سنة & السن & \multirow{3}{*}{ النمو } \\
\hline 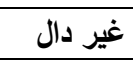 & 0.11 & 0.52 & 166.54 & 1.63 & 166.52 & سم & الطول & \\
\hline غير دال & 0.52 & 0.14 & 64.15 & 0.51 & 64.27 & كجم & 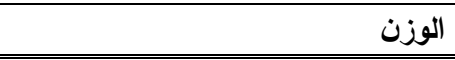 & \\
\hline غير دال & 0.63 & 0.11 & 2.09 & $\overline{0.24}$ & 2.05 & ل درجة & لدحرجة خلفية وقوف على اليدين & \multirow{5}{*}{ المهارية } \\
\hline 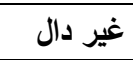 & 0.54 & 0.32 & 2.31 & 0.36 & 2.33 & درجة & عجلة فتحا من الجري & \\
\hline 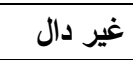 & 0.87 & 0.47 & 2.33 & 0.51 & 2.30 & 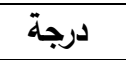 & العجلة ضم مع ربع لفة & \\
\hline 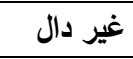 & 0.96 & 0.36 & 2.41 & 0.36 & 2.45 & درجة & وقوف على اليدين دحرجة امامية & \\
\hline 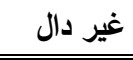 & 0.21 & 0.21 & 2.14 & 0.41 & 2.12 & درجة & وقوف على اليدين نزول على الصدر & \\
\hline غير دال & 0.54 & 0.17 & 52.61 & 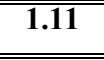 & 52.65 & درجة & التدفق النفسي & \\
\hline 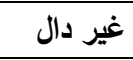 & 0.63 & 0.32 & 28.45 & 0.31 & 28.65 & سم & الوثب العمودي من الثبات & \multirow{4}{*}{ البننية } \\
\hline 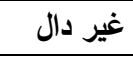 & 0.55 & 0.22 & 13.11 & 0.87 & 13.65 & زمن & الجري المكوكي & \\
\hline 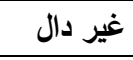 & 0.15 & 0.18 & 5.38 & 0.17 & 5.44 & سم & ثنى الجزع اسفل & \\
\hline 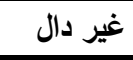 & 0.35 & 0.21 & 3.44 & 0.31 & 3.48 & زمن & الوقوف على عارضة التوازن & \\
\hline
\end{tabular}

يتضـح من الجدول (2) أنه لا توجد فروق ذات دلاتلاتة إحصائية بين مجموعتي البحث

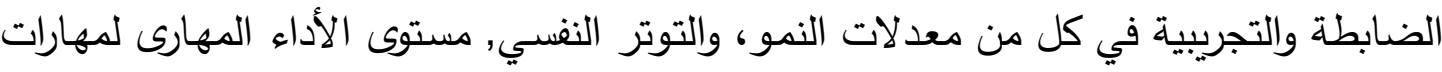

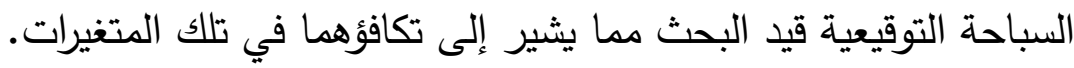
أدوات جمع البيانات المستخدمة: 1

- الرستاميتر لقياس الطول (بالسنتيمتر). - ميزان طبي لقياس الوزن (بالكيلو جرام). - شريط قياس (بالسنتيمتر). - ساعة إيقاف لحساب الزمن (بالثانية).

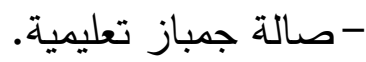

2- اختبار مستوى التدفق النفسي (قيد البحث)

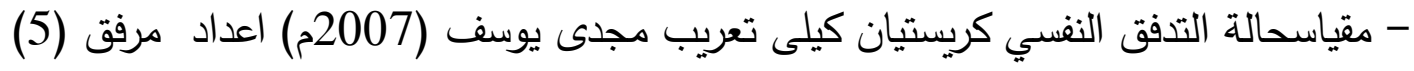
3- اختبار مستوى الاداء المهارى على جهاز الحركات الارضية 
اختبار مستوى الأداء المهاري على جهاز الحركات الارضية درجات لجنة ثلاثية من

$$
\text { 4- اختبار القدرات البدنية }
$$

- اختبار الوثبالعموديمنالثباتلقياس القدرة العضلية للرجلين.

$$
\text { - - اختبار الجريالمكوكيلقياس مستوى الرشاقة. }
$$

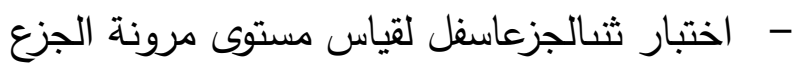

- - اختبار الوقوفعلدعارضةالتوازن لقياس مستوى التوازن.

$$
\text { المعاملات العليمة للاختبارات المستخدمة في البحث }
$$

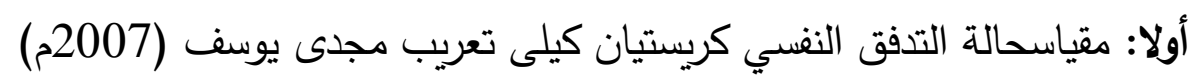

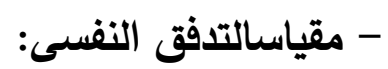

صمم هذا المقياس كريستيان كيلى Kristian Kiili (الاست (2006م) تعريب مجدى حسين يوسف (2007م) ويتكون المقياس من (22) عبارة في الاتجاه الإيجابي لقياس مستوى التدفق النفسي ويتدرج المقياس بتقسيمات ( 1-2-3-4-5) والدرجة العليا تدل على مستوى التوافق الاتج النفسي الجيد.

المعاملات العلمية لمقياسالتدفق النفسي في البحث الحالي: " معامل صدقلمقياسالتدفق النفسي. قامتالباحثتبتطبيقالمقياس على عينة استطلاعية قوامها (8) طالبات من طالبات الفرقة الثالثة بكلية التربية الرياضية جامعة حلوان وقد استخدمتطريقة الاتساق الداخليبإيجاد معامل

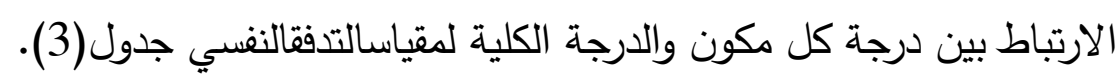




\section{جدول ( 3 )}

معاملات الارتباط بين درجة كل مكون والدرجة الكلية لاختبار الاسترخاء ( التدفق النفسى ) (8=ن ن )

\begin{tabular}{|c|c|c|c|c|c|}
\hline الدلالة & معامل الارتباط & العبارات & الدلالة & معامل الارتباط & العبارات \\
\hline دال & 0.614 & 12 & دال & 0.684 & 1 \\
\hline دال & 0.628 & 13 & دال & 0.650 & 2 \\
\hline دال & 0.745 & 14 & دال & 0.710 & 3 \\
\hline دال & 0.751 & 15 & دال & 0.751 & 4 \\
\hline دال & 0.628 & 16 & دال & 0.745 & 5 \\
\hline دال & 0.681 & 17 & دال & 0.698 & 6 \\
\hline دال & 0.621 & 18 & دال & 0.678 & 7 \\
\hline دال & 0.687 & 19 & دال & 0.658 & 8 \\
\hline دال & 0.632 & 20 & دال & 0.651 & 9 \\
\hline دال & 0.617 & 21 & دال & 0.698 & 10 \\
\hline دال & 0.621 & 22 & دال & 0.661 & 11 \\
\hline
\end{tabular}

قيمة " ر " الجدولية عند مستوى دلالة معنوي ( 0,05 ) = 0,497

يتضح من الجدول (3) أن ، قيم معاملات الارتباط بين درجة كل مكون والدرجة الكلية

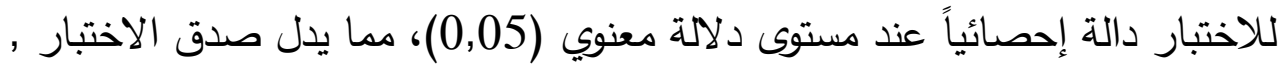
معامل ثبات لمقياس التدفق النفسي : قامت الباحثة بتطبيق الاختبار على عينة قوامها (8) طالبات من طالبات الفرقة الثالثة

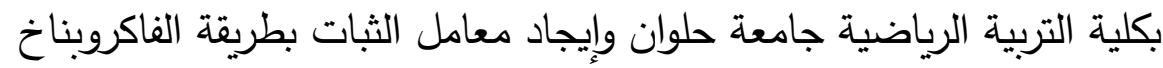
جدول (4)

معامل الاختبار بطريقة الفاكروبناخ( التدفق النفسى ) $8=$ ن

\begin{tabular}{|c|c|c|c|}
\hline معامل إلفا & الانحراف المعياري & المتوسط الحسابي & \\
\hline $0.797 *$ & 3.514 & 52.69 & الارجة الكلية \\
\hline
\end{tabular}

يتضح من الجدول (4) أن ، قيمة معامل الارتباط بطريقة الفاكرونباخ دالة إحصائياً عند

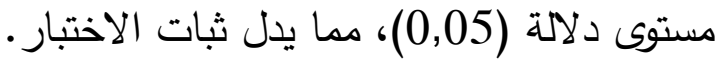


المعاملات العلمية لاختبار المتغيرات البلنية والمهارية في البحث الحالي: قامتالباحثتانبتطبيقالاختبار على عينة استطلاعية قوامها (8) طالبات من طالبات الفرقة الثالثة بكلية التربية الرياضية جامعة حلوان وقد استخدمتا طريقة المقارنة الطريفة بين الربيع الاعلى والربيع الادنكما في جدول(5).

جلول رقم ( 5 ( )

معامل صدق التمايز لاختبارات المتغيرات البلنية والاداء المهارى في الجمباز $8=\dot{ن}$

\begin{tabular}{|c|c|c|c|c|c|c|c|}
\hline \multirow{2}{*}{ 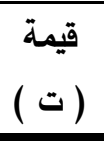 } & \multicolumn{2}{|c|}{ الربيع الادنى } & \multicolumn{2}{|c|}{ الربيع الاعلى } & \multirow{2}{*}{ |لقياس } & \multirow{2}{*}{ المتغيرات } & \multirow[t]{2}{*}{ p } \\
\hline & $\varepsilon^{ \pm}$ & 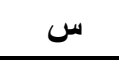 & $\varepsilon^{ \pm}$ & 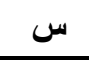 & & & \\
\hline 3.25 & 0.35 & 1.85 & 0.14 & 2.55 & درجة & لدحرجة خلفية وقوف على اليدين & 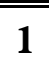 \\
\hline 3.21 & 0.47 & 1.69 & 0.26 & 2.52 & درجة & عجلة فتحا من الجري & 2 \\
\hline 3.69 & 0.66 & 1.75 & 0.36 & 2.64 & درجة & العجلة ضم مع ربع لفة & 3 \\
\hline 3.14 & 0.21 & 1.68 & 0.52 & 2.74 & درجة & وقوف على اليدين دحرجة امامية & 4 \\
\hline 3.22 & 0.78 & 1.67 & 0.14 & 2.44 & درجة & وقوف على اليدين نزول على الصدر & 5 \\
\hline 3.98 & 0.32 & 25.31 & 0.11 & 30.11 & سم & الوثب العمودي من الثبات & 6 \\
\hline 3.14 & 0.17 & 14.32 & 0.74 & 12.12 & زمن & الجري المكوكي & 7 \\
\hline 3.21 & 0.21 & 3.36 & 0.21 & 5.14 & سم & ثنى الجزع اسفل & 8 \\
\hline 3.59 & 0.87 & 2.60 & 0.29 & 3.44 & زمن & الوقوف على عارضة التوازن & 9 \\
\hline
\end{tabular}

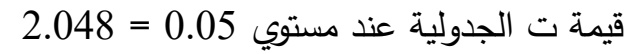
يتضح من جدول رقم(5) أن هناك فروقاً دالة إحصائيا بين الربيع الاعلى والربيع الادنى

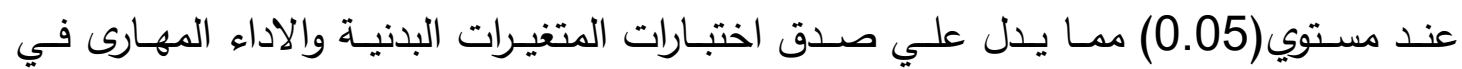

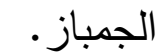

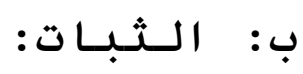
قامت الباحثتان بحساب معامل ثبات اختبارات المتغيرات البنيـة والاداء المهارى في الجمباز عن طريق تطبيق الاختبارات علي مجموعة من طالبات الفرقة الثالثة بكلية التربية

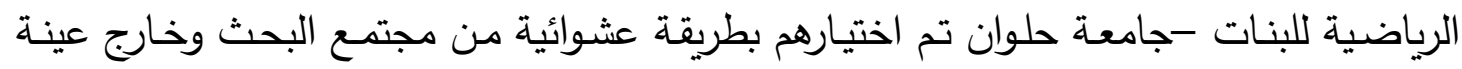

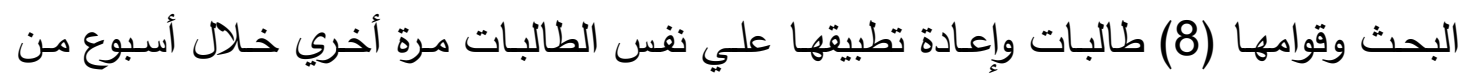

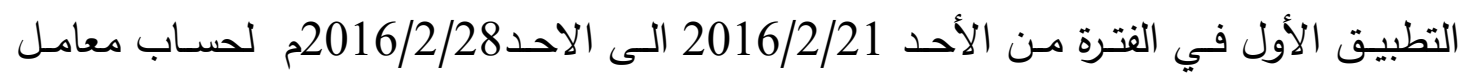
الثبات ويدل معامل الارتباط بين التطبيق الأول والتطبيق الثاني علي معامل ثبات اختبارات الاتبات

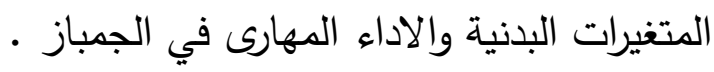


جدول (6)

معامل الثبات لاختبارات المتغيرات البذنية والاداء المهارى في الجمباز

$8=\dot{0}$

\begin{tabular}{|c|c|c|c|c|c|c|c|}
\hline \multirow{2}{*}{ معامل الارتباط } & \multicolumn{2}{|c|}{ التطبيق الثاني } & \multicolumn{2}{|c|}{ التطبيق الاول } & \multirow{2}{*}{ وحدة } & \multirow{2}{*}{ المتغيرات } & \multirow[t]{2}{*}{ T } \\
\hline & $\varepsilon^{ \pm}$ & 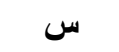 & $\varepsilon^{ \pm}$ & 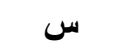 & & & \\
\hline 0.960 & 0.31 & 2.65 & 0.36 & 2.62 & درجة & دحرجة خلفية وقوف على اليدين & 1 \\
\hline 0.950 & 0.25 & 2.55 & 0.11 & 2.50 & 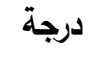 & عجلة فتحا من الجري & 2 \\
\hline 0.974 & 0.11 & 2.65 & 0.52 & 2.61 & درجة & العجلة ضم مع ربع لفة & 3 \\
\hline 0.960 & 0.63 & 2.77 & 0.17 & 2.75 & 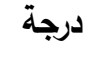 & وقوف على اليدين دحرجة امامية & 4 \\
\hline 0.950 & 0.17 & 2.49 & 0.84 & 2.45 & درجة & وقوف على اليدين نزول على الصدر & 5 \\
\hline 0.941 & 0.21 & 29.90 & 0.32 & 29.50 & 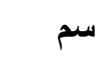 & الوثب العمودي من الثبات & 6 \\
\hline 0.968 & 0.25 & 12.15 & 0.36 & 12.10 & 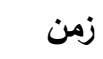 & الجري المكوكي & 7 \\
\hline 0.974 & 0.41 & 5.20 & 0.11 & 5.15 & 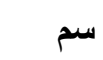 & ثنى الجزع اسفل & 8 \\
\hline 0.922 & 0.17 & 3.48 & 0.14 & 3.45 & 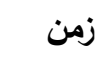 & الوقوف على عارضة التوازن & 9 \\
\hline
\end{tabular}

يتضـح من جدول رقم (6) وجود علاقة ارتباطيه دالة بين التطبيق الأول والثاني لعينة

الدراسة الاستطلاعية مما يدل على ثبات اختبارات المتغيرات البدنية والاداء المهارى قيد البحث.

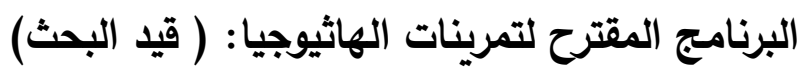

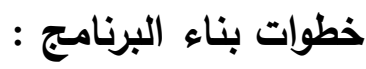

(1) تحديد الهرف من تمرينات الهاثيوجيا:

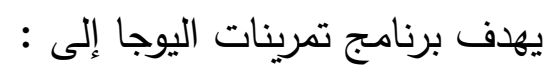

* تحسين مستوى التدفق النفسي لدى لاعبات الجمباز . تمبنات

* تحسين مستوى الاداء المهارى لبعض المهارات على جهاز الحركات الارضية.

(2)تحديد أسس وضع برنامج تمرينات الهاثيوجيا:

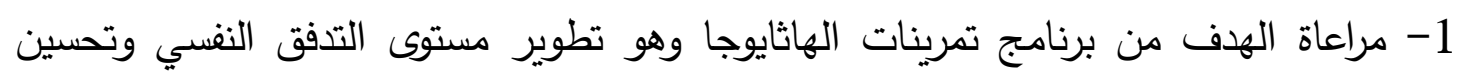

مستوى الاداء المهارى في جمباز الحركات الارضية.

2- ملائمة محتوى البرنامج لخصائص النمو للمرحلة|لسنية.

3-مرونة البرنامج و قبوله للتطبيق العملي.

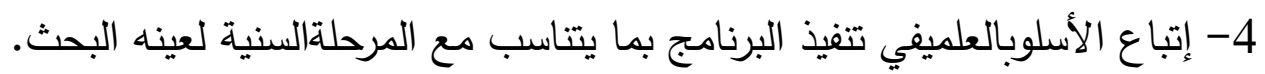

5- مراعاة الثمول والدقةفي إختيار و تتفيذ البرنامج.

(3)(تخطيط برنامج تمرينات الهاثيوجيا: 
بعد اطلاعالباحثتان على المراجع والأبحاث العلميةالمتخصصةفي تمريناتالهاثايوجا

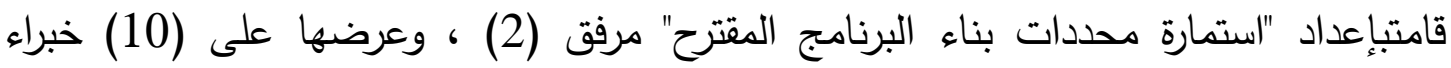
مرفق(1) وحساب نسبة الاتفاق كما هو موضح بجدول (7) وبناء على ما سبق وفقاً لتحديد

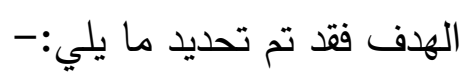

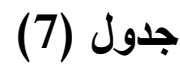

أراء الخبراء في عناصر برنامج تمرينات الهاثيوجيا

\begin{tabular}{|c|c|c|}
\hline رأى الخبراء & عناصر البرنامج & p \\
\hline شهزين & مده البرنامج & 1 \\
\hline (8)(سابيع & عدد الأسابيع & 2 \\
\hline 3وحدة & عدد الوحدات فى كل أسبوع & 3 \\
\hline 60 & زمن كل وحده & 4 \\
\hline
\end{tabular}

يتضح من جدول (7)أن ، جاءت نتائج العرض على الخبراء وعددهم (10) خبراء

والمبينة أسمائهج مرفق (1) وجاءت موافقة الخبراء بان تكون مدة البرنامج المقترح لتمرينات الهاثايوجا (2) شهرين بواقع (8) اسابيع , ويتكون كل أسبوع من (3) وحدات , مدة كل ولن وحدة (60)

الخطوات التنفيذية للاراسة القياسات القبلية :

قامتالباحثتان بأجراء القياسات القبلية على العينةالأساسية للبحث مجموعتي البحث التجريبية والضابطتفيالفترة من 2 / 3 / 2016م وحتى 3 / 2016/3 م.

- تطبيق برنامج تمرينات اليوجا: أ: أ: مجموعة البحث التجريبية:

قامتالباحثان بتطبيق برنامج تمرينات الهاثايوجا على طالبات الفرقة الثالثة بكلية التربية

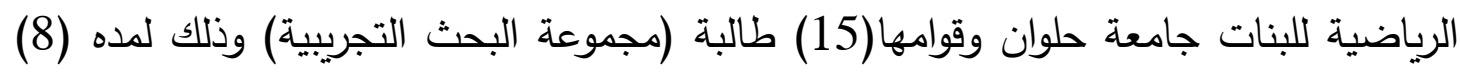

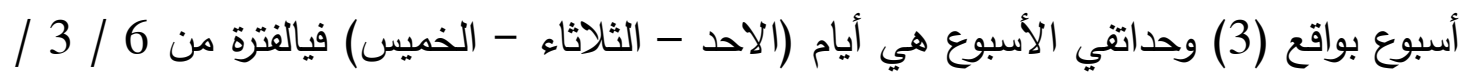

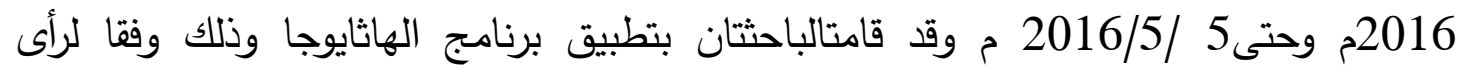
الخبراء وتستغرق الوحدة(60) ق. ق. 
قامت الباحثتان بمتابعة طالبات مجموعة البحث الضابطة وعددهم (15) طالبة

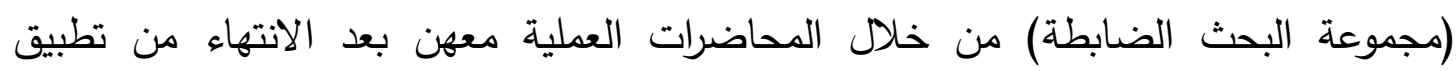
التجربة الأساسية لمدة (8) أسبوع. - القياسات البعدية : تم أجراء القياسات البعدية بعد الانتهاء من تطبيق برنامج تمرينات الهاثايوجا ومباشرة

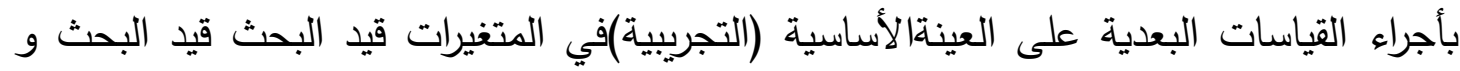

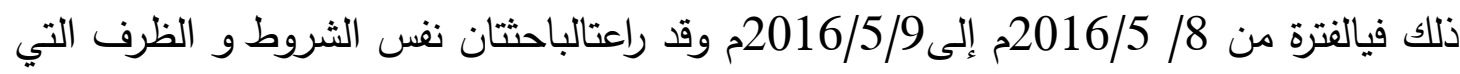
تم إتباعهافي القياسات القبلية. المعالجات الإحصائية : - الانحراف المعياري - - - اختبار دلاله الفروق ومعدل التحسن. - - معامل الالتواء. - - الوسيط. - - معامل الارتباط. 
جلول (8)

دلالة الفروق بين القياسين القبلي والبعدي في مستوى التدفق النفسي والأداء المهارى في

جمباز الحركات الارضية لاى طالبات المجموعة التجريبية"

$15=ن$

\begin{tabular}{|c|c|c|c|c|c|c|c|c|c|c|}
\hline \multirow[b]{2}{*}{ مستوى } & \multirow[b]{2}{*}{ 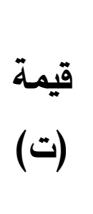 } & \multirow[b]{2}{*}{ نسبة } & \multirow{2}{*}{ الفتروق الفين } & \multicolumn{2}{|c|}{ القياس البعدي } & \multicolumn{2}{|c|}{ القياس القبلي } & \multirow[b]{2}{*}{ القياس } & \multirow{2}{*}{\multicolumn{2}{|c|}{ المتغيرات }} \\
\hline & & & & $\underline{\underline{E}}$ & $\underline{E}$ & 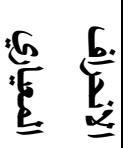 & $\underline{E}$ & & & \\
\hline دال & 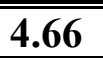 & \%72.69 & 39.00 & 0.21 & 91.65 & 1.11 & 52.65 & درجة & التدفق النفسي & \\
\hline دال & 4.81 & \%93.77 & 1.96 & 0.11 & \begin{tabular}{|l|l|}
4.05 \\
\end{tabular} & 0.11 & 2.09 & لدرجة & دحرجة خلفية وقوف على اليدين & \\
\hline 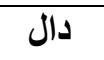 & 4.32 & $\% 83.98$ & 1.94 & 0.32 & 4.25 & 0.32 & 2.31 & درجة & عجلة فتحا من الجري & \\
\hline دال & 4.78 & $\% 78.96$ & 1.84 & 0.17 & 4.17 & 0.47 & 2.33 & درجة & العجلة ضم مع ربع لفة & الاداء \\
\hline 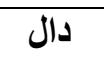 & 4.31 & $\% 84.64$ & 2.04 & 0.32 & 4.45 & 0.36 & 2.41 & درجة & وقوف على اليدين لحرجة امامية & 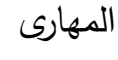 \\
\hline 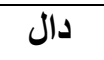 & 4.17 & $\% 91.58$ & 1.96 & 0.11 & 4.10 & 0.21 & 2.14 & درجة & وقوف على اليدين نزول على الصدر & \\
\hline
\end{tabular}

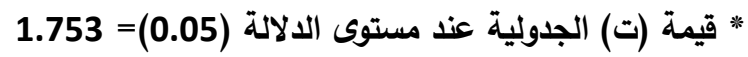

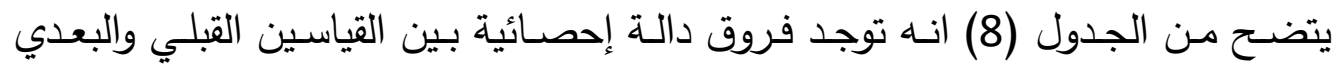

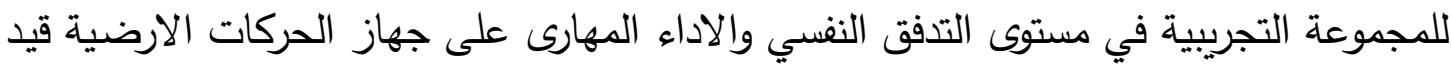
البحث ولصالح القياس البعدي حيث أن جميع قيم (ت) المحسوبة أكبر من قيمة (ت) الجدولية

عند مستوى الدلالة (0.05). 


$$
\text { جلول (9) }
$$

دلالة الفروق بين القياسين القبلي والبعدي في مستوى التدفق النفسي والأداء المهارى في جمباز الحركات الارضية لاى طالبات المجموعة الضابطة"

$$
15=\dot{0}
$$

\begin{tabular}{|c|c|c|c|c|c|c|c|c|c|c|}
\hline \multirow[b]{2}{*}{ مستوى الدلالة } & \multirow[b]{2}{*}{ 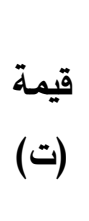 } & \multirow[b]{2}{*}{ التحسنة } & \multirow[b]{2}{*}{ المتوبن الفروق } & \multicolumn{2}{|c|}{ القياس البعدي } & \multicolumn{2}{|c|}{ القياس القبلي } & \multirow[b]{2}{*}{ القياس } & \multirow{2}{*}{\multicolumn{2}{|c|}{ المتفيرات }} \\
\hline & & & & 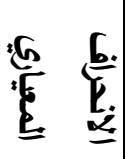 & $\underline{E}$ & 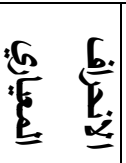 & $\underline{E}$ & & & \\
\hline دال & 3.47 & $\% 35.37$ & 1.81 & 0.14 & 71.22 & 0.17 & $\overline{52.61}$ & درجة & التدفق النفسي & \\
\hline دال & 3.62 & $\% 51.21$ & 1.05 & 0.21 & 3.10 & $\overline{0.24}$ & 2.05 & درجة & دحرجة خلفية وقوف على اليدين & \\
\hline 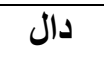 & 3.11 & \%33.90 & 0.79 & 0.22 & 3.12 & 0.36 & 2.33 & درجة & عجلة فتحا من الجري & \\
\hline 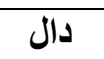 & 3.17 & $\% 37.82$ & 0.87 & 0.17 & 3.17 & 0.51 & 2.30 & درجة & العجلة ضم مع ربع لفة & الاداء \\
\hline دال - ال & 3.26 & \%28.57 & 0.70 & 0.31 & 3.15 & 0.36 & 2.45 & 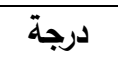 & وقوف على اليدين دحرجة امامية & 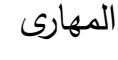 \\
\hline دال & 3.19 & \%51.88 & 1.10 & 0.24 & 3.22 & 0.41 & 2.12 & 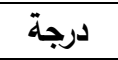 & وقوف على اليدين نزول على الصدر & \\
\hline
\end{tabular}

$$
\text { * قيمة (ت) الجدولية عند مستوى الدلالة (0.05)= } 1.753
$$

يتضـح من الجدول (9) انـاه توجد فروق دالـة إحصـائية بين القياسين القبلي والبعدي

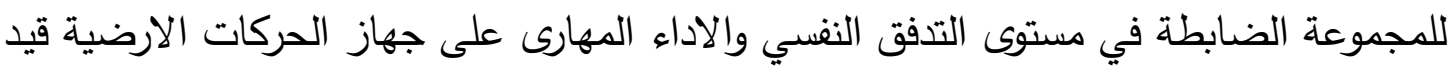

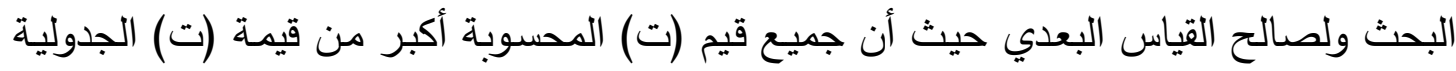

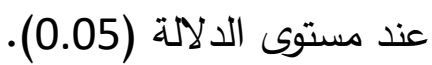




$$
\text { جدول (10) (ن) }
$$

دلالة الفروق بين القياسين البعديين في مستوى التدفق النفسي والأداء المهارى في جمباز

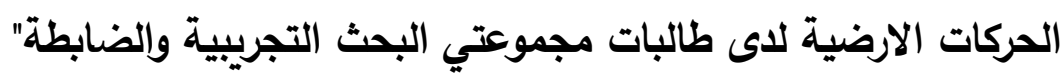

\section{$15=2 \dot{0}=1$ ن}

\begin{tabular}{|c|c|c|c|c|c|c|c|c|}
\hline \multirow{2}{*}{ مستوى الالالة } & \multirow{2}{*}{ قيمة } & \multicolumn{2}{|c|}{ الضابطة } & \multicolumn{2}{|c|}{ التجريبة } & \multirow{2}{*}{ القياس } & \multirow{2}{*}{\multicolumn{2}{|c|}{ المتغيرات }} \\
\hline & & 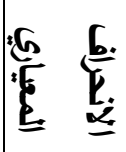 & $\underline{E}$ & 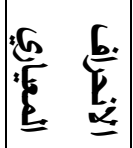 & $\underline{E}$ & & & \\
\hline دال & 3.28 & 0.14 & 71.22 & 0.21 & 91.65 & درجة & التدفق النفسي & \\
\hline دال & 3.24 & 0.21 & 3.10 & 0.11 & 4.05 & درجة & دحرجة خلفية وقوف على اليدين & \multirow{5}{*}{ الاداء } \\
\hline 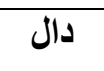 & 3.62 & 0.22 & 3.12 & 0.32 & 4.25 & درجة & عجلة فتحا من الجري & \\
\hline 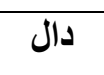 & 3.87 & 0.17 & 3.17 & 0.17 & 4.17 & درجة & العجلة ضم مع ربع لفة & \\
\hline 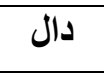 & 3.62 & 0.31 & 3.15 & 0.32 & 4.45 & درجة & وقوف على اليدين دحرجة امامية & \\
\hline 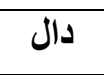 & 3.87 & 0.24 & 3.22 & 0.11 & 4.10 & درجة & وقوف على اليدين نزول على الصدر & \\
\hline
\end{tabular}

* قيمة (ت) الجدولية عند مستوى الدلالة (0.05)= 1.697

يتضـح من الجدول (10) انهـ توجد فروق ذات دلالمة إحصائية بين مجموعتي البحث

الضابطة والتجريبية في مستوى التدفق النفسي والاداء المهارى في جمباز الحركات الارضية قيد

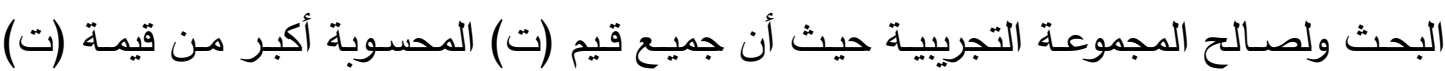

$$
\text { الجدولية عند مستوى الدلالة (0.05). }
$$

مناقشة النتائج

يتضـح من الجدول (8) انـه توجد فروق دالـة إحصـائية بين القياسين القبلي والبعدي

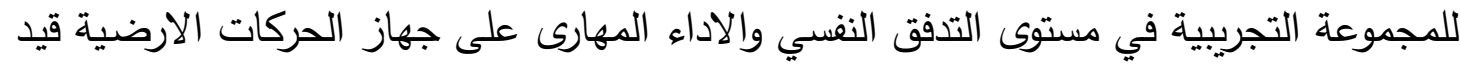

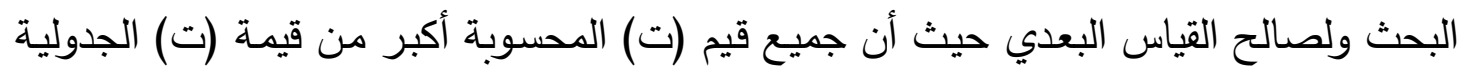

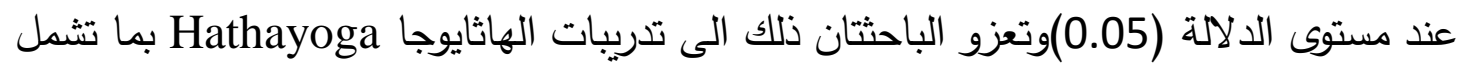

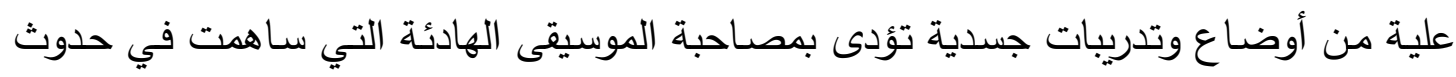

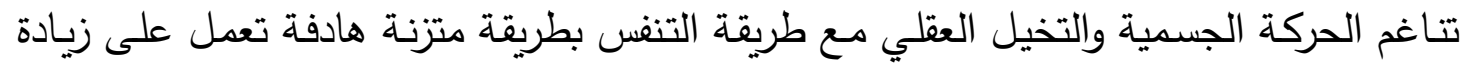
المرونة ومدى الحركة وتحسن من توازن الجسم ، كما أنها تتمى لدى الفرد قوته على التركيز

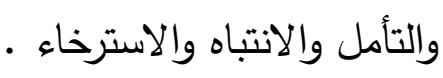




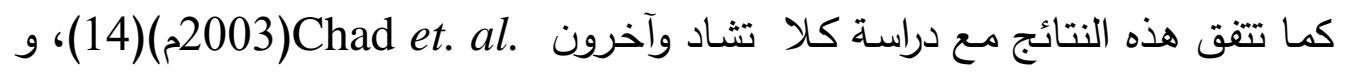
ولام وآخرون .Lamet. al) 2002)(20) الى ان تدريبات الهاثايوجا بما تشمل علية من تدريبات

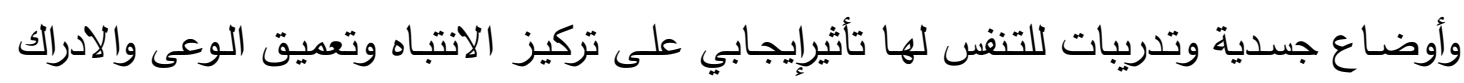

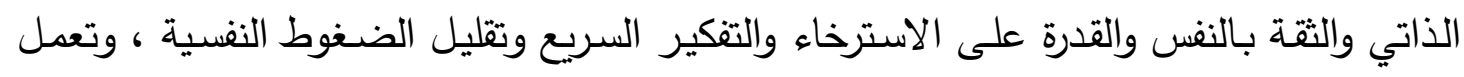

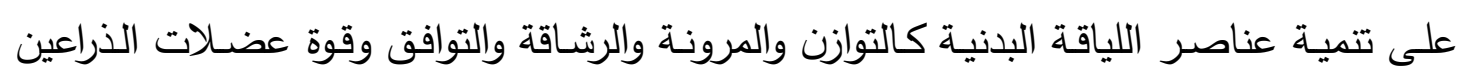
والرجلين والظهر والبطن.

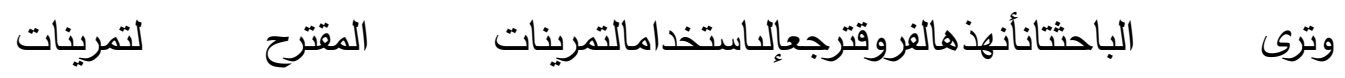
الهاثايوجاالمتترحةلتنميةوالتطويرمستوبالاداء المهارى والتدفق النفسي لجمباز الحركات الارضية التربية

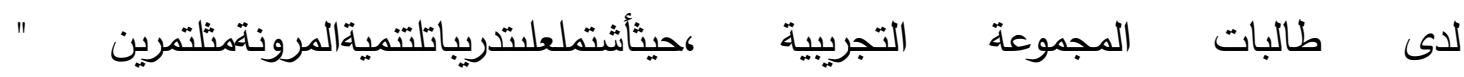
الوقوفمعرد الجسملأعليثمالانحناء للإمامومسكحائط

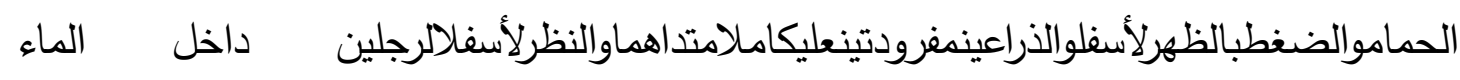
كوتمرين بينهمقبضتهوالقدمينمتجهينلإمام منوضعالوقوفثنيالركبتينقليلاولفالجذعيميناوناويساراوالذراعينبجانبالجسموالنظرللخلف.

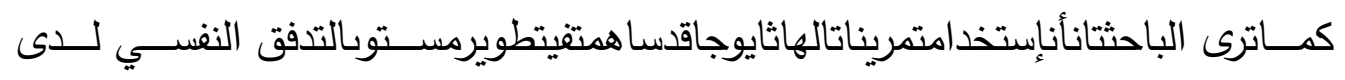

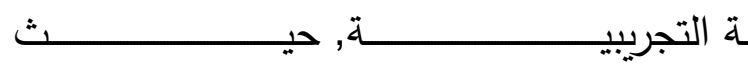
طالب

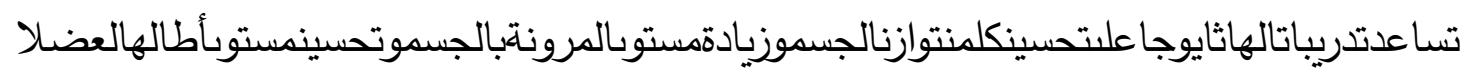
تالعاملتبالجسمكماتسا عدفيزيادةقوةالمفاصلوالأربطة العاملة علدالمفاصل.

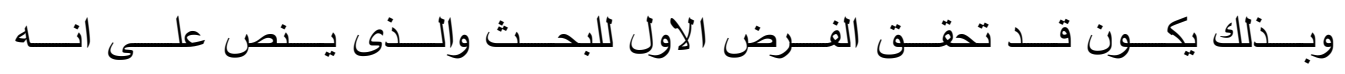

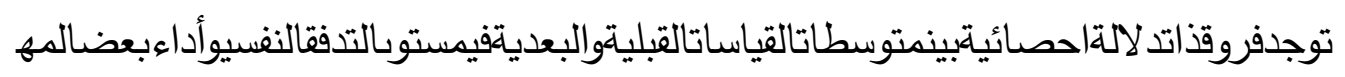

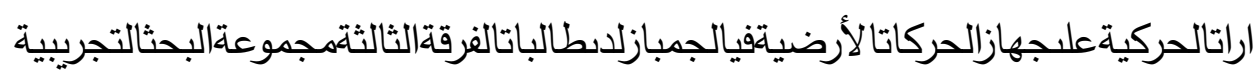

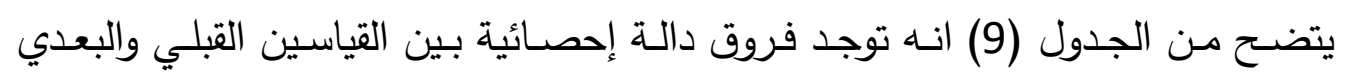

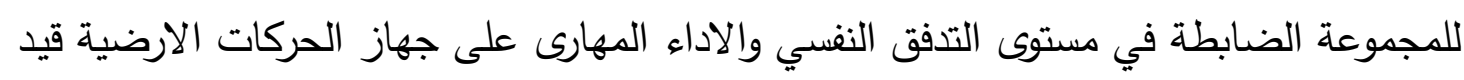

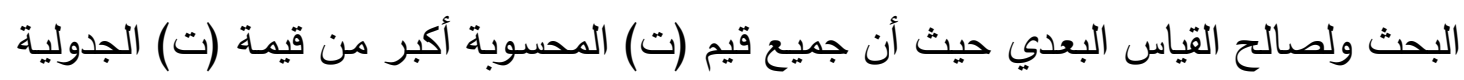

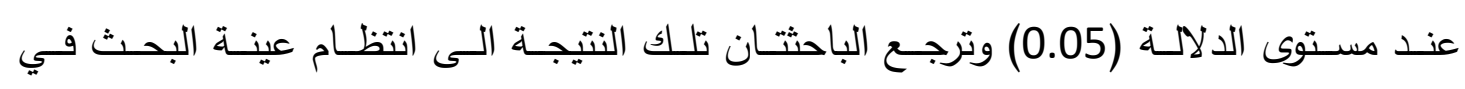
المحاضرات العملية. 
كما تتقق هذه النتائج مع ما اشار الية علياء جاسم(2016م) (7) حيث اشارات إلى أن

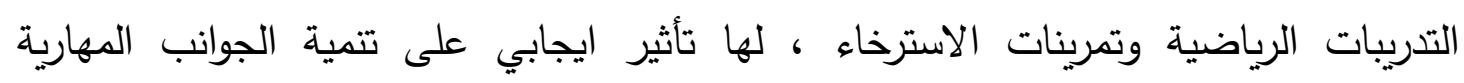
والقدرات الحركية والبدنية وكذلك الكفاءة الحركية والنفسية.

وأن النشاط البدني يساعد على تحسين الصحة العامة، إلا أن البرامج المقننة للأنشطة

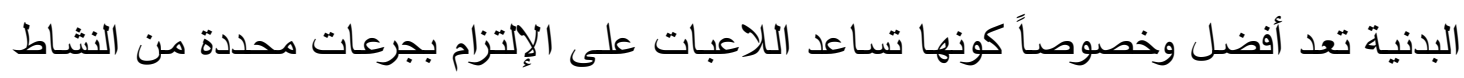

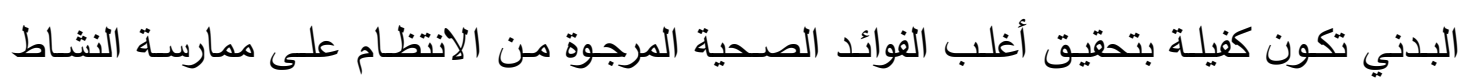
البدني •(35: (35)

وبذلك يكون قد تحقق الفرض الثاني للبحث والذى ينص على انه توجد فروق ذات دلالة

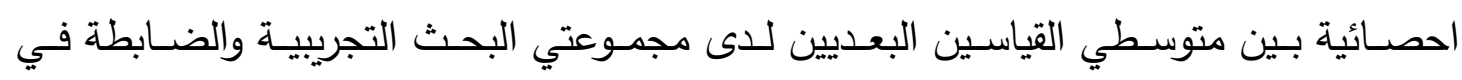

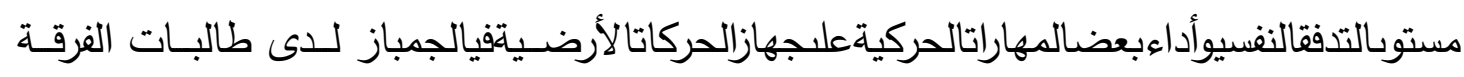
الثالثة مجموعة البحث التجريبية. يتضـح من الجدول (10) انه توجد فروق ذات دلالة إحصائية بين مجموعتي البحث

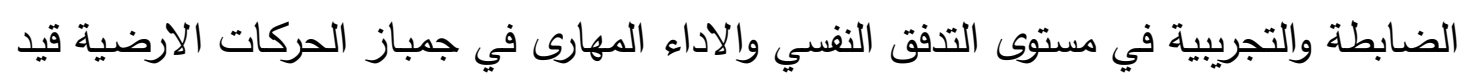

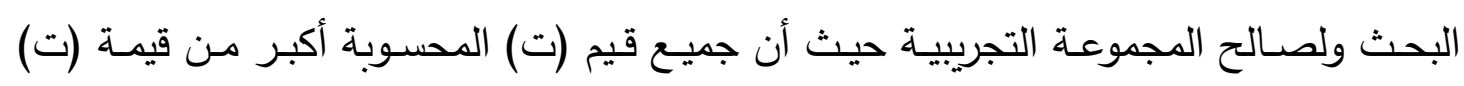
الجدولية عند مستوى الدلالة (0.05).

وتعزو الباحثتان هذا التحسن على الهجموعة التجريبية الى ممارسة تدريبات الهاثايوجا

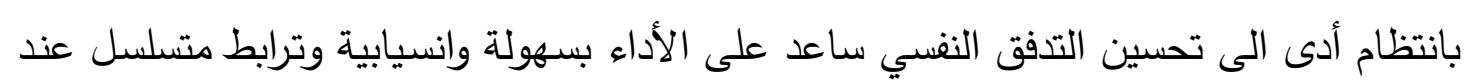

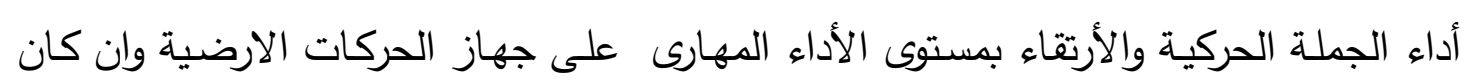

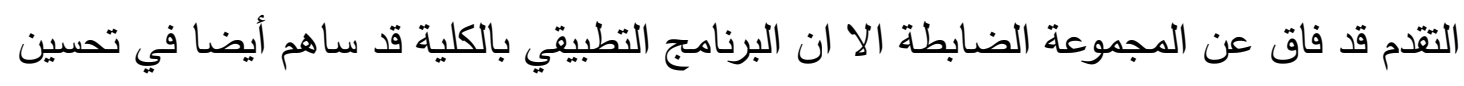
مستوى الأداء الذى يحتوى على مجموعة من التدريبات على المهارات المكونة للجملة الحركية.

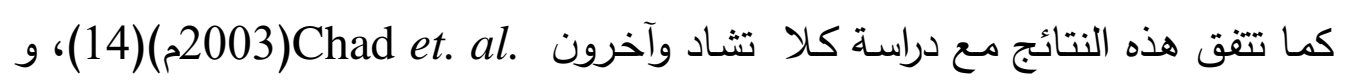
ولام وآخرون .Lam et. al(2002م)(20)الى ان تدريبات الهاثايوجا تساعد على التنمية النفسية والبدنية وتحسن في مستوى أداء الجملة الحركية على جهاز الحركات الارضية.

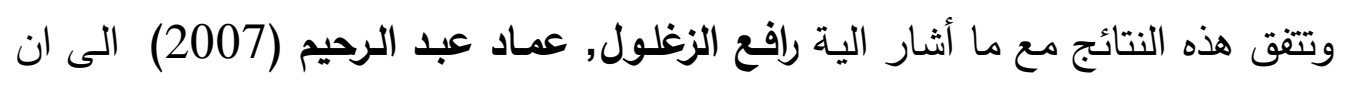

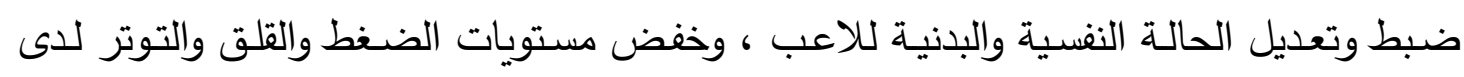

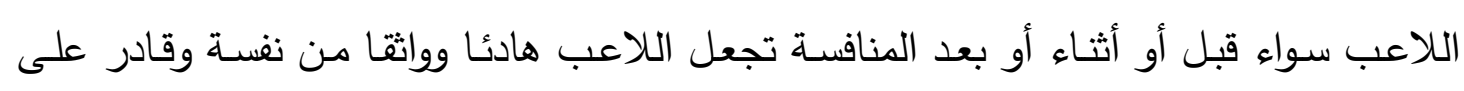

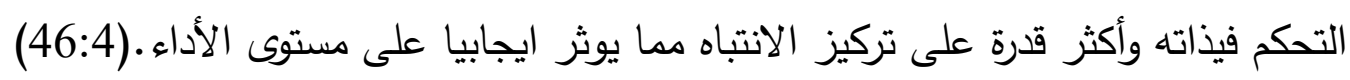


وبذلك يكون قد تحقق الفرض الثالث للبحث والذى ينص على انه توجدفروق ذات دلالة

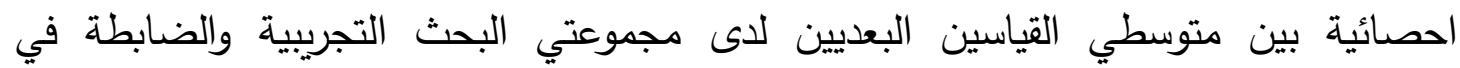

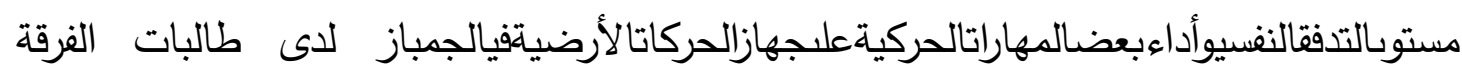
الثالثة مجموعة البحث التجريبية. الاستنتاجات

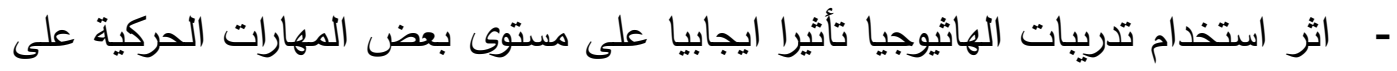
جهاز الحركات الارضية لاى طالبات المجموعة التجريبية.

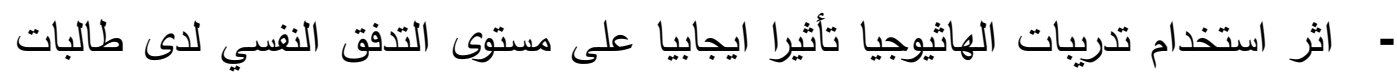
المجموعة التجريبية. - - تأثير تدريبات الهاثيوجيا اثر ايجابيا اكثر من البرنامج المطبق داخل الكلية على مستوى

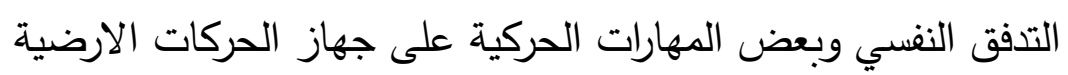
التوصيات - - استخدام تدريبات الهاثيوجيا المقترحة لما لها من تأثير إيجابي على تحسن الصفات النفسية والمهارية في جمباز الحركات الارضية. - - - 


\section{المراجع}

1- الهامعبد العظيم فرج ، أمال محمد مرسى (2005) : تأثير برنامجين للتمرينات الهاثايوجا

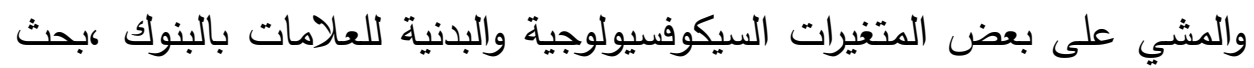

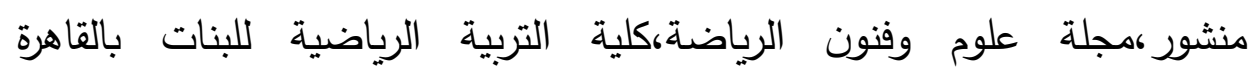
، المجلدالثاني والعشرون ,يناير •

2- أمال محم يوسف (2004): فاعلية برنامج الهاثايوجا على بعض المتغيرات النفسية

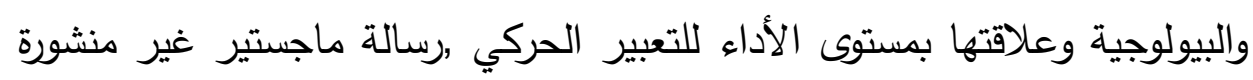

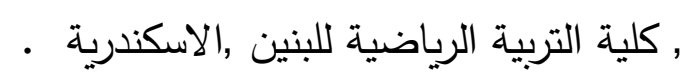

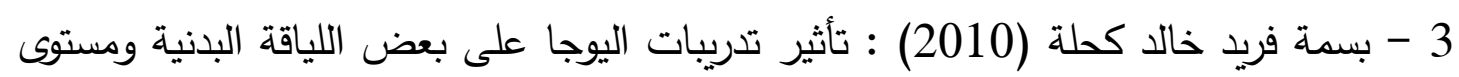

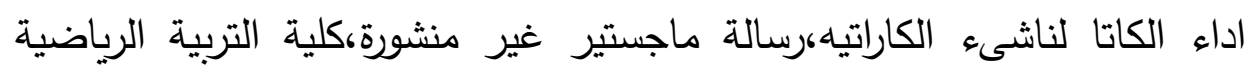
للبنات،جامعة حلوان ،القاهرة. 4 - رافع النصير الزغلول, عماد عبد الرحيم الزغلول (2007) : علم النفس المعرفي،دار الشروق ،الاردن.

5- ريم محسن حسن(2004): فاعلية برنامج تمرينات هوائية وتمرينات اليوجا الألم اسفل

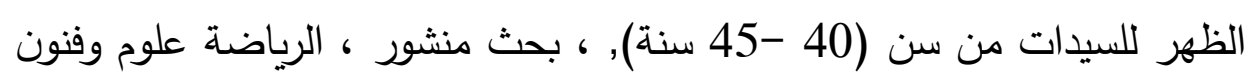

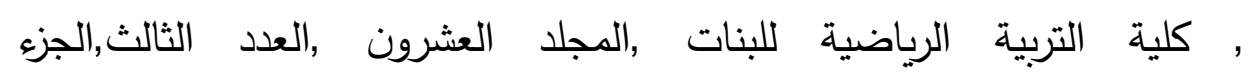
الثاني, يناير ,القاهرة.

6 - شيماء عبدالله عطية (2009) : " تأثيرالهاثايوجا على بعض المتغيرات النفسية ومستوى الاداء في التعبير الحركي"، رسالة ماجستير غير منشورة،كلية التربية الرياضية

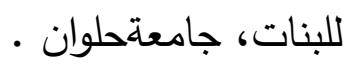

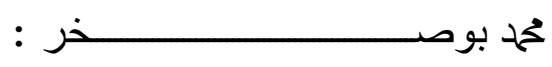
7 - علي تأثيربرنامجتدريبيوفقحدداتحالة|التدفقالنفسيعلفعالية|لتصويلناشئكرةالســلة , رســالة ماجستير , كلية التربية الرياضية, جامعة الاسكندرية,2016م. 8- مجدى حسن يوسف(2014م) فينومينولوجيا التدفق النفسي في المجـال الرياضسي , دار الوفاء للطباعة والنشر , الاسكندرية. 9- محمد إبراهيم شحاتة : "تدريب الجمباز المعاصر" ,دار الفكر العربي , القاهرة , 2003م.

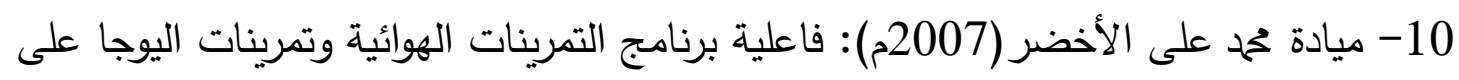
القدرة على الاسترخاءومواجه الضغوط النفسية رسالة ماجستير غير منشورة, , كلية التربية الرياضية للبنات ,القاهرة. 
11- ميثث مطير حميدي(2015م) التدفق النفسي وعلاقته بالتوجه الدفاعي للاعبي كرة القدم

بالدوري الممتاز بالعراق, رسـالة ماجستير , كليـة التربية الرياضية للبنـات, جامعة

الاسكندرية.

12- هايدي أحمد سـامى توفيق تأثير العبء الإدراكى على التدفق النفسي ومستوى الأداء

المهارى لـى لاعبي الكومتيـة في رياضـة الكاراتيـه , رسـالة دكتوراه, كليـة التربية

$$
\text { الرياضية للبنات, جامعة حلوان,2016م. }
$$

13- هويدا العصرة واخرون(2008): تأثير برنامج اليوجا باستخدام الكرة السويسرية على بعض التصان

المتغيرات البدنية والنفسية وحساسية الأذن الداخلية ربحث منشور ,مجلة علمية

$$
\text { للتربية البدنية والرياضية ,العدد الاول ,أكتوبر ,القاهرة . }
$$

14- Chad timmermans.et.al(2003):the effectiveness yoga exersice on exity and mood for athletes.

15- Damodaran et.al(2002):the effectiveness yoga exercise on the psychological and physiological abilities of woman and men at the mid age

16-Gawinski, kali (2012) : the effects of type of yoga training on physiological and psychological fitness in college aged men and women. university of Windsor (Canada)

17-Gallo Samantha(2009) : A comparison of flexibility after a single-bout

of Ashtanga and Bikram Yoga. California State University.

18- Geralds, george(2000): using of gymnastic safety manual, united stats gymnastics federation, seconded, Indianapolis.

19- Gould D., Deiffenbach K., Moffett A. (2002): "Psychological Characteristics and their development in Olympic Champions", Journal of Applied Sport Psychology, 14, 172-204.

20- Lam, eddie,(2002) hang, james:development and validation of a racquet ball skill test battery young adult beginners ,measurement in physical education and exercise

21-Malathi and damodran (2000) :the the effectiveness yoga exercise on axity during the day.

22- Miladakrajci (2003): menteltrining and breathing technique and yoga as apartof psychological trining for difrentsport.

23- Smernova, E, I., (1995), The rale of circute training method on the preparation of Gymnatic female biggeres aged 10-11 years, Theory and practce and physical culture, No. 9, P42.

24- Steven .d,(2005) coaching gymnastics successfully Engle Wood Cliffs Prentice shall 